\title{
Sedimentological characteristics of ice-wedge polygon terrain in Adventdalen (Svalbard) - environmental and climatic implications for the late Holocene
}

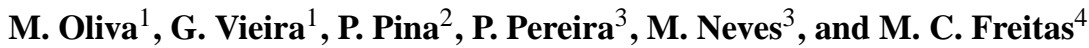 \\ ${ }^{1}$ Institute of Geography and Spatial Planning - Centre for Geographical Studies, University of Lisbon, Lisbon, Portugal \\ ${ }^{2}$ CERENA/University of Lisbon, Lisbon, Portugal \\ ${ }^{3}$ Environmental Management Center, Mykolas Romeris University, Ateities St. Vilnius, Lithuania \\ ${ }^{4}$ Universidade de Lisboa, Faculdade de Ciências, Centro de Geologia, Lisbon, Portugal
}

Correspondence to: M. Oliva (oliva_marc@yahoo.com)

Received: 31 March 2014 - Published in Solid Earth Discuss.: 7 May 2014

Revised: 10 July 2014 - Accepted: 11 July 2014 - Published: 1 September 2014

\begin{abstract}
Ice wedges are widespread periglacial features in the landscape of Adventdalen, Svalbard. The networks of ice wedges have created areas with well-developed polygonal terrains in the lowest fluvial terraces in this valley. We have examined the sedimentological characteristics of the northern and southern banks of the Advent river for palaeoenvironmental purposes. The base of two sedimentary sections reported radiocarbon dates of 3.3 and $3.9 \mathrm{ka} \mathrm{BP}$, respectively. The northern site is constituted by three very different lithostratigraphical units, which suggests that their formation should be related to different environmental and climate conditions. By contrast, the southern section shows a rather homogeneous composition, with no significant variations in grain size and organic matter content. In both cases the uppermost sediments are constituted by a thick aeolian deposit. According to our data, warmer climate conditions may have prevailed during the mid Holocene until $3.3 \mathrm{ka} \mathrm{BP}$ with widespread peat formation in the valley bottom. Subsequently, a period with alternating soil formation and aeolian sedimentation took place from 3 to $2.5 \mathrm{ka} \mathrm{BP}$, probably due to increasing climatic severity. During the last millennium a long-term cooling trend has favoured aeolian deposition in the lowest part of Adventdalen.
\end{abstract}

\section{Introduction}

Permafrost environments support a wide range of periglacial landforms. One of the most scenic and widespread features characteristic of the periglacial landscape are ice-wedge polygon terrains. Nowadays, ice wedges only form at high latitudes, not in mid-latitude mountain environments. The presence of ice wedges is indicative of permafrost conditions, though they can be active or inactive under the present-day climate regime. The process of formation of ice-wedge polygons has been mainly investigated in Arctic permafrost environments, with a focus on the role of sediments and climate conditions in the development of these landforms (French, 2007). Over the last two decades several studies have focused on the interaction between air and soil temperatures in the process of cracking (Burn, 1990; Mackay 2000; Christiansen, 2005; Fortier and Allard, 2005). Other papers have examined the sedimentary record in areas where terrestrial polygonal networks are well-developed (Fortier and Allard, 2004; Fortier et al., 2006) as well as the isotopic composition of the ice (Schwamborn et al., 2006; Opel et al., 2011) as two complementary sources from which to infer past environmental conditions.

This research is focused on Adventdalen (Spitsbergen Island, Svalbard), an area where ice-wedge polygon terrains are widespread. The high Arctic is precisely one of the areas on Earth that has recorded the strongest warming trend over the last decades: since the beginning of the 20th century mean annual air temperature (MAAT) in Svalbard increased 
$0.23^{\circ} \mathrm{C}$ per decade (Humlum et al., 2011a). In parallel, ground temperatures have shown a gradual increase during the last decade in Svalbard, the region recording the warmest permafrost temperatures in the high Arctic (Christiansen et al., 2010). Thus, significant changes in the dynamics of the terrestrial ecosystem are expected in response to this climate trend. The formation of ice wedges may also be affected by this fast-changing climate scenario; in this context, over recent years, several studies have monitored the cracking process in Svalbard (Christiansen, 2005; Watanabe et al., 2013).

In order to better understand the environmental dynamics in ice-wedge polygon terrains, it is of crucial importance to take into account the topographical and geomorphological characteristics of these areas as well as the sedimentological properties and past environmental evolution in the area where polygons are distributed. Present-day landscape in Adventdalen is a consequence of Pleistocene glaciations and post-glacial (Holocene) environmental dynamics. The Lower Adventdalen remained covered by ice with a thickness of at least ca. $1000 \mathrm{~m}$ during the last glaciation (Lønne and Nemec, 2004). Enhanced orbital forcing during the early Holocene induced higher temperatures in the high Arctic that produced shrinking and upvalley retreat of Svalbard glaciers. This process favoured the post-glacial rebound of the valley bottom, which has been quantified as being $60-70 \mathrm{~m}$ over the Holocene (Lønne and Nemec, 2004). Evidence of warmer conditions in Svalbard until $4 \mathrm{ka}$ BP come from a wide range of sedimentary records, such as marine cores (Salvigsen, 2002; Forwick and Vorren, 2010), lacustrine records (Birks, 1991; Svendsen and Mangerud, 1997; Snyder et al., 2000) or glaciers (Liestøl, 1988; Humlum et al., 2005). Humlum (2005) proposes MAAT as high as $0-3^{\circ} \mathrm{C}$ for coastal areas, which means that permafrost conditions at lower altitudes should have developed only during the mid and late Holocene. According to data retrieved from lake sediments, warm conditions extended from 8 to 4-5 ka BP (Birks, 1991; Holmgren et al., 2010), with a maximum of ca. $+2{ }^{\circ} \mathrm{C}$ around $6 \mathrm{ka} \mathrm{BP}$ (Wanner et al., 2008; Sundqvist et al., 2010). After $4 \mathrm{ka} \mathrm{BP}$, temperatures started dropping in the Northern Hemisphere, particularly in the North Atlantic Region, as reflected by Greenland ice cores (Vinther et al., 2006), with a declining linear temperature trend of $-0.52{ }^{\circ} \mathrm{C}$ per 1000 years (Humlum et al., 2011b) and enhanced climate variability (Moberg et al., 2005). Over the late Holocene, ocean circulation changes have determined a succession of colder and warmer periods in the high Arctic (Skirbekk et al., 2010; Moros et al., 2012), which favoured glacier advances and retreats in Svalbard (Hald et al., 2001; Grinsted et al., 2006; Divine at al., 2011; Velle, 2012) as well as landscape changes in the major valleys (Härtel, 2011).

The study of the sediments in areas with ice-wedge polygonal networks provides insights on their formation and physical and chemical weathering processes, allowing us to understand the local palaeoenvironmental and palaeoclimatic evolution. There is no agreement on whether, in cold re- gions, weathering is mainly driven by temperature or water availability. According to Hall et al. (2002) the weathering processes are more limited by moisture availability than by temperature; therefore, weathering can be intense even at low temperatures (Hall, 1997, 2004; Matsuoka and Murton, 2008). The water fluxes in cold-climate environments are assumed to be important because weathering is dominated by physical processes (Egli et al., 2014); thus the intensity and the frequency of freeze-thaw cycles are factors of critical importance. Chemical weathering in periglacial areas is also an important mechanism in terms of geomorphic work (Allen et al., 2001; Thorn et al., 2001), being controlled by the type of lithology, biological activity, organic matter, topography, aspect, water availability, the structure of the hydrologic system and the age of exposure/deglaciation (Egli et al., 2014). Previous work developed indexes, such as the chemical index of alteration (CIA) (Daviel et al., 2011), to assess soil weathering based on geochemical properties, .

The purpose of this paper is to present new data about the environmental dynamics in the ice-free area of the Adventdalen floor during the mid and late Holocene and its connection with climate variability. To do so, this research aims at

1. examining the sedimentological record and weathering processes in two exposures from both the northern and southern banks of Adventelva where polygonal networks are present;

2. characterizing the geochemical record in one of the studied profiles (ADV.20);

3. reconstructing the environmental evolution in the area and its connection with palaeoclimatic trends in Svalbard.

\section{Study area}

This research is focused on the Lower Adventdalen, in western central Spitsbergen Island (Svalbard archipelago). The study area is located in proximity to Longyearbyen, the largest settlement of the archipelago, at a latitude of $78^{\circ} \mathrm{N}$ (Fig. 1). The climate corresponds to a polar tundra climate (ET) in the Köppen climate system. The MAAT between 1961 and 1990 in Longyearbyen was $-6.7^{\circ} \mathrm{C}$ rising to $-4.6^{\circ} \mathrm{C}$ between 1981 and 2010 , with a large interannual variability, especially during winter months (Førland et al., 2011). No significant trends have been inferred for precipitation over the last decades, with a mean annual precipitation of $190 \mathrm{~mm}$ mainly concentrated during the summer season.

Topography in the study area consists of peaks, ridges and plateaus cut by Adventdalen, which runs SE-NW towards Isfjorden. Adventdalen is a typical U-shaped glacial valley covered by unconsolidated glacial, colluvial, alluvial, marine and aeolian deposits dating to the Holocene. Tertiary coal seams are exposed on the slopes, composed mainly of 


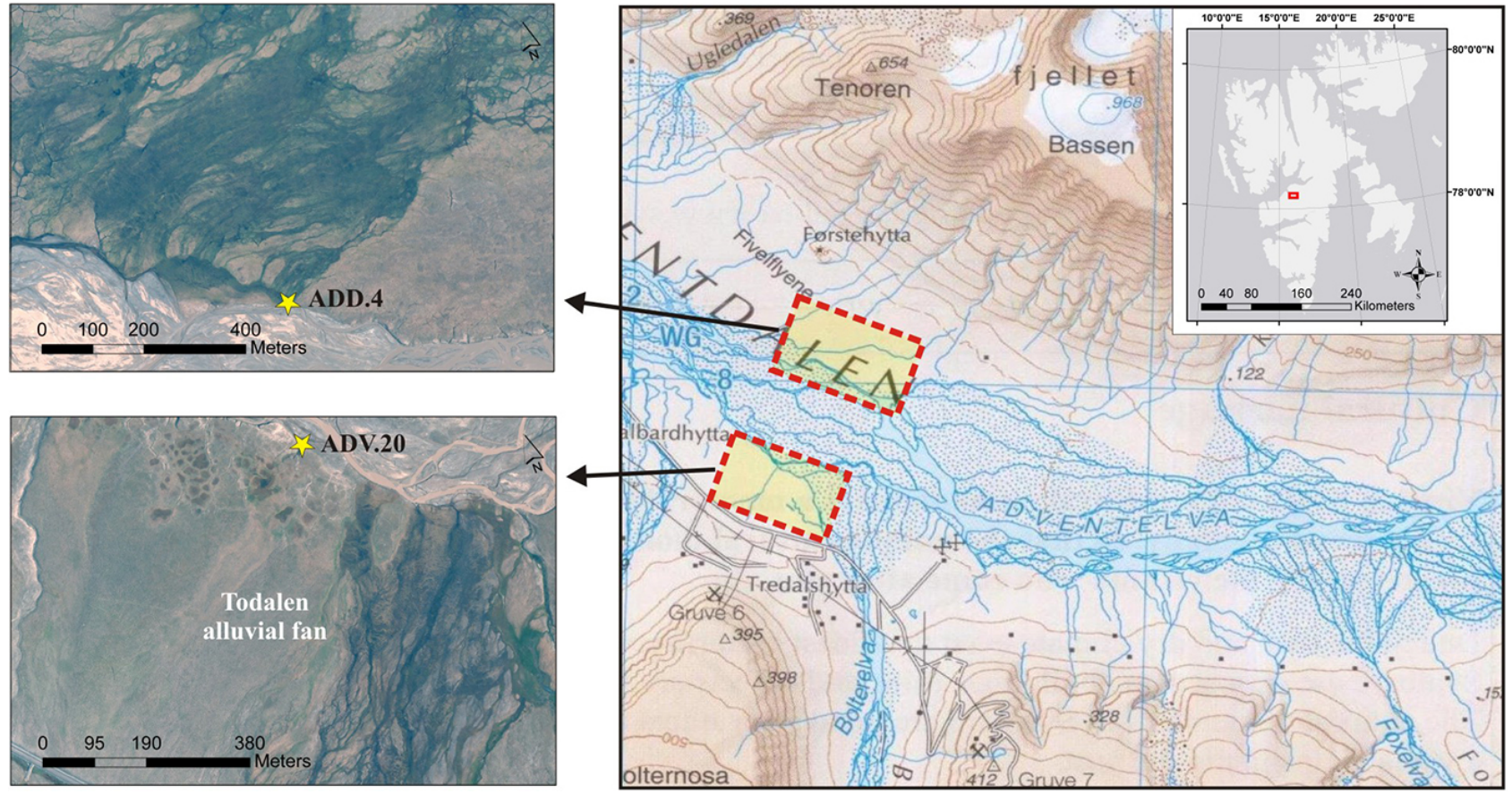

Figure 1. Location of Adventdalen in Svalbard (right) and position of the sites (left).

Jurassic to Triassic deposits (Major et al., 2001). Tributary streams draining to Adventelva have built large alluvial fans along the valley sides. One of the study areas is, in fact, located in Todalen alluvial fan, on the left margin of the river (Fig. 1).

The equilibrium line altitude of the glaciers in Svalbard varies from $200 \mathrm{~m}$ a.s.l. along the coast to $>600 \mathrm{~m}$ in the central eastern parts of Spitsbergen (Hagen et al., 1993). In the ice-free areas of Svalbard ( $40 \%$ of the island) permafrost is continuous, reaching a thickness of $\sim 100 \mathrm{~m}$ in coastal areas and up to $\sim 400-500 \mathrm{~m}$ in the highlands (Liestøl, 1976). Permafrost in the valley floors and coastal areas probably dates to the late Holocene, whereas in the mountains it dates back to the last glaciation or is even older (Humlum et al., 2003). The warmest permafrost conditions in the high Arctic are recorded in Svalbard despite a significant temperature increase detected during the last years (Christiansen et al., 2010).

Vegetation in the valley floor is typical of high-Arctic tundra environments, with a mixture of grasses. Aeolian sediments cover the lowest glaciofluvial terraces of Adventelva (Fig. 1), where ice-wedge polygonal networks are a highly common form of patterned ground (Sørbel and Tolgensbakk, 2002; Ulrich et al., 2011; Pina, 2014). Here, the thermalcontraction cracking of the ground is responsible for the formation of ice-wedge polygonal networks. This process occurs during cold spells in winter when air temperatures drop to below $-20^{\circ} \mathrm{C}$ and ground temperatures to below $-15^{\circ} \mathrm{C}$ near the top of the permafrost above the ice wedge (Chris- tiansen, 2005). Between 2000 and 2007 the thickness of the active layer at the end of the summer season at the bottom of Adventdalen oscillated between 74 and $104 \mathrm{~cm}$ (Christiansen and Humlum, 2008).

The average dimension (mean axis) of the polygons in the study areas is about $12 \mathrm{~m}$, but their sizes range from ca. 2 to $70 \mathrm{~m}$. Also, most of the polygons are low-centred and have 5,6 and 7 neighbours, although polygons with a number of neighbours in the range of 3 to 11 have been identified. The majority of networks exhibit a non-orthogonal pattern, but spatial clusters of orthogonal behaviours of the troughs were also detected in some networks. Consequently, the trivalent vertices (intersection of three troughs) largely prevail over the tetravalent ones (four troughs) in the analysed networks (Saraiva et al., 2012).

Two sites have been examined: (1) a sedimentary sequence on the lowest part of the Todalen alluvial fan, on the southern bank of Adventelva; (2) a sedimentary sequence located in a glaciofluvial terrace on the northern bank of the river (Fig. 2).

The first area, where the alluvial fan of Todalen river meets Adventelva, constitutes a case study where several ongoing experiments are conducted on a very detailed scale to identify the factors conditioning the distribution of periglacial landforms and to understand the process of ice-wedge and mudboil formation. Their distribution shows a consistent spatial pattern across the study area and is well-related to changes in the sedimentological properties across the alluvial fan (Watanabe et al., 2012a). The topographical position with respect to the Todalen river and Adventelva conditioned the 

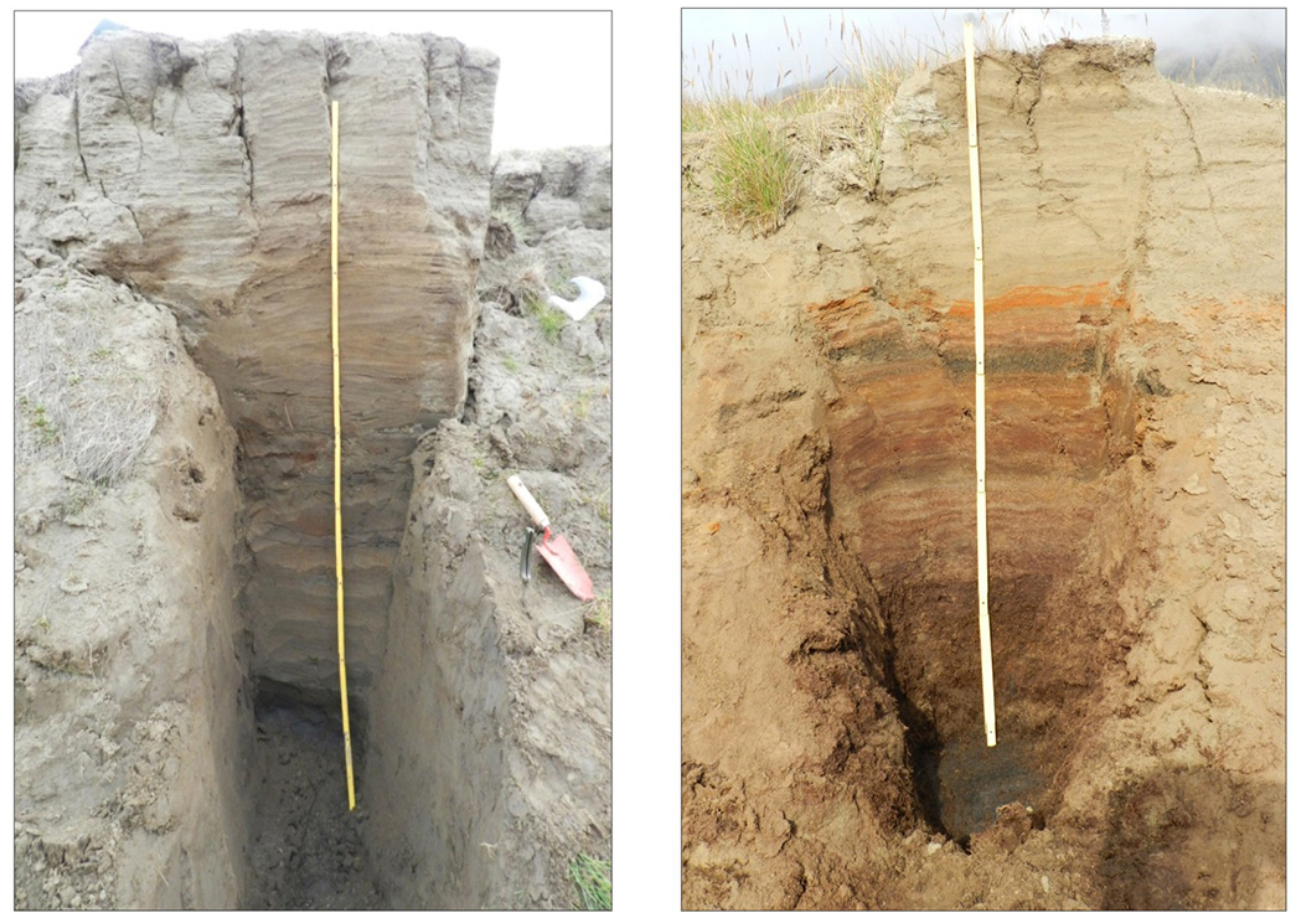

Figure 2. Pictures of the two long sections studied: ADV.20 (left) and ADD.4 (right).

sources of the sediments as well as the geomorphological features distributed in this alluvial fan (Härtel, 2011). Todalen alluvial fan is a high-energy environment where coarse sediments (gravels and boulders) were deposited throughout the Holocene; in fact, the formation of alluvial fan deltas in Adventdalen is thought to have started during the early Holocene (Lønne and Nemec, 2004). While tens of mudboils are distributed in the upper part of the alluvial fan, ice-wedge polygons are abundant in the distal part. Recent investigation has shown that the areas where mudboils are present experienced large amount of frost heave associated with intensive ice segregation in comparison with the ice-wedge polygon sites (Watanabe et al., 2012a). Therefore, gravels are expulsed to the surface and generate these mudboils. At specific study sites Watanabe at al. (2012b) have shown that soil composition, soil moisture conditions and winter ground thermal regime together with snow depth are crucial factors controlling the formation of mudboils and ice-wedge polygons in this Arctic tundra landscape.

\section{Materials and methods}

Fluvial erosion has exposed sections on the river terraces where sediment exposures can be examined at high resolution. Samples from two sections in the northern (ADD.4) and southern margins (ADV.20) of the river were collected according to the different lithostratigraphic units observed in the field and characterized for palaeoenvironmental reconstruction.

\subsection{Laboratory analysis}

Soil organic matter content was determined by Loss on Ignition (LOI) at $550^{\circ} \mathrm{C}(3 \mathrm{~h})$. For grain size measurements, samples were first pretreated with hydrogen peroxide $\left(\mathrm{H}_{2} \mathrm{O}_{2}\right)$ to eliminate the organic fraction and subsequently analysed with a Malvern Mastersizer 2000. Analyses were undertaken at the laboratory of the Geology Center of the University of Lisbon. Ten samples (plant fragments) from both sedimentary sequences were AMS ${ }^{14} \mathrm{C}$ Accelerator mass spectrometry (AMS) dating at the Centro Nacional de Aceleradores of Sevilla (Spain) in order to establish the geochronological time frame. All radiocarbon ages discussed in this research have been converted to calendar ages with the program CALIB 7.0 (Reimer et al., 2013). The geochemical composition of ten samples (fine-grained fraction $(\varnothing<2 \mathrm{~mm})$ ) from different lithostratigraphical units of the ADV.20 section was acquired by X-ray fluorescence (XRF) at the Institute of Geosciences of the Federal University of Rio Grande do Sul (Brazil) following standard analytical procedures. The chemical index of alteration was calculated using the following formula: $\mathrm{CIA}=\left[\left(\mathrm{Al}_{2} \mathrm{O}_{3}+\mathrm{CaO}+\mathrm{Na}_{2} \mathrm{O}+\mathrm{K}_{2} \mathrm{O}\right) / \mathrm{Al}_{2} \mathrm{O}_{3}\right] \mathrm{x}$ 100 (Nesbit and Young, 1982). 


\subsection{Statistical analysis}

Some descriptive statistics of the studied variables were examined; specifically, these were the following: mean (M), minimum (Min), maximum (Max), standard deviation (SD) and coefficient of variation (CV). The normal data assessment was carried out with the Shapiro-Wilk test. Since not all distributions respected the Gaussian distribution, data were transformed using logarithms in order to meet normal distribution requirements. A one-way ANOVA (analysis of variance) was carried out in order to identify significant differences between soil profiles in LOI, sand, silt and clay percentages. With the transformed data, Pearson correlation coefficients were calculated to identify relations between depth and the studied variables. Significant differences between soil profile and correlations between variables and soil depth were considered at a $p<0.05$.

\section{Results}

\subsection{Sedimentological characteristics in the northern bank of Adventelva (ADD.4)}

The studied sedimentary sequence has a thickness of $1.3 \mathrm{~m}$, since permafrost was found at $1.2 \mathrm{~m}$ depth and it was not possible to examine the deeper lithostratigraphic units. Three very different units were observed in this section (Fig. 3):

- Unit A: $82-130 \mathrm{~cm}$. The basal layer of this section is constituted by a slightly decomposed peat layer with very high organic matter content (LOI $>50 \%$ ). The mineral particles existing in this unit correspond mainly to silts, which constitute ca. $70 \%$ of the total.

- Unit B: $41-82 \mathrm{~cm}$. The intermediate unit contains an alternation of more organic layers (15-20\% LOI) and silty layers with lower organic matter proportion (10 $15 \%)$. These layers show a variable thickness ranging from 2 to $8 \mathrm{~cm}$. Slight differences in terms of grain size have been observed. An overall trend towards a lower proportion of organic matter in the sediments is detected the higher up one goes in this unit, LOI values declining from above $20 \%$ to $10 \%$ in the upper layers.

- Unit C: $0-41 \mathrm{~cm}$. The top of the section is composed by aeolian silts and fine sands interbedded with thin layers of medium sands. Several parallel vertical cracks are observed down to $50 \mathrm{~cm}$ depth. The proportion of sand reaches $60 \%$ of the mineral fraction in some pockets, while in the rest it constitutes ca. $40 \%$. The percentage of organic matter is very low and stable along this uppermost unit (LOI $2-3 \%$ ).

The chronological framework of this section is based on eight AMS ${ }^{14} \mathrm{C}$ datings (Table 1), although some of them have been discarded. The basal peaty layer shows two very similar datings for the bottom and the top of this unit (3.3 $\mathrm{ka} \mathrm{BP})$. After this period, a phase with alternating aeolian deposition and organic formation took place. However, the two uppermost datings in this section did not offer consistent results, so no precise age control for the beginning of the deposition of the thick aeolian cover was obtained.

\subsection{Sedimentological characteristics in the southern bank of Adventelva (ADV.20)}

In contrast to the section from the northern margin of the river, no peat layer was observed at this site despite the fact that permafrost was much deeper than in ADD.4. Permafrost was found at $1.9 \mathrm{~m}$ depth, which constituted the bottom of this section. Two slightly different lithostratigraphic units were observed (Fig. 4):

- Unit A: $95-190 \mathrm{~cm}$. This unit is constituted by several relatively organically rich bands $2-3 \mathrm{~cm}$ thick that show slight increase in the organic matter content (LOI 5$7 \%$ ) interbedded in a matrix of silty poorly-organic sediments (LOI 3-4\%). No significant grain size changes were observed along this unit, with a proportion of sands ranging from 25 to $30 \%$.

- Unit B: 0-95 cm. The upper metre is composed by a silty matrix that shows a gradual increase in sand content towards the surface, reaching $30-35 \%$ of the total. Some pockets of sand were also observed in the uppermost sediments, constituting $40 \%$ of the sediments in these layers. Here, cracks related to frost and desiccation cracking are very common. In this unit the LOI percentages are even lower than at the base (2-4\%), with very few plant fragments.

Only two samples from this section were ${ }^{14} \mathrm{C}$ dated. The bottom organic band returned a date of $3913 \pm 81$ years BP and the upper organic layer yielded a date of $1008 \pm 75$ years BP.

Soil organic matter content was significantly higher in ADD.4 than in ADV.20 section $(F=15.76, p<0.001)$. Sand content was much higher in ADV.20 $(F=9.46, p<$ $0.01)$ and the silt proportion was more greater in ADD.4 $(F=10.19, p<0.01)$. No significant differences were observed in the percentage of clay between the two soil profiles $(F=3.26, p>0.05)$. The $\mathrm{CV}$ of these parameters was higher in ADD.4 than in ADV.20. Regarding the evolution of these variables with soil profile depth, significant positive correlations were observed in LOI, silt and clay percentages in ADD.4, while sand content showed a significant negative correlation. In ADV.20 only a significant positive correlation of LOI with soil depth was identified (Table 2).

Geochemical properties were only analysed in ADV.20. On average, $\mathrm{SiO}_{2}$ and $\mathrm{Al}_{2} \mathrm{O}_{3}$ were the most abundant minerals in the ADV. 20 sequence, with percentages of $73.1 \%$ and $11.3 \%$, respectively, while $\mathrm{MnO}(0.04 \%)$ and $\mathrm{Cr}_{2} \mathrm{O}_{3}$ 


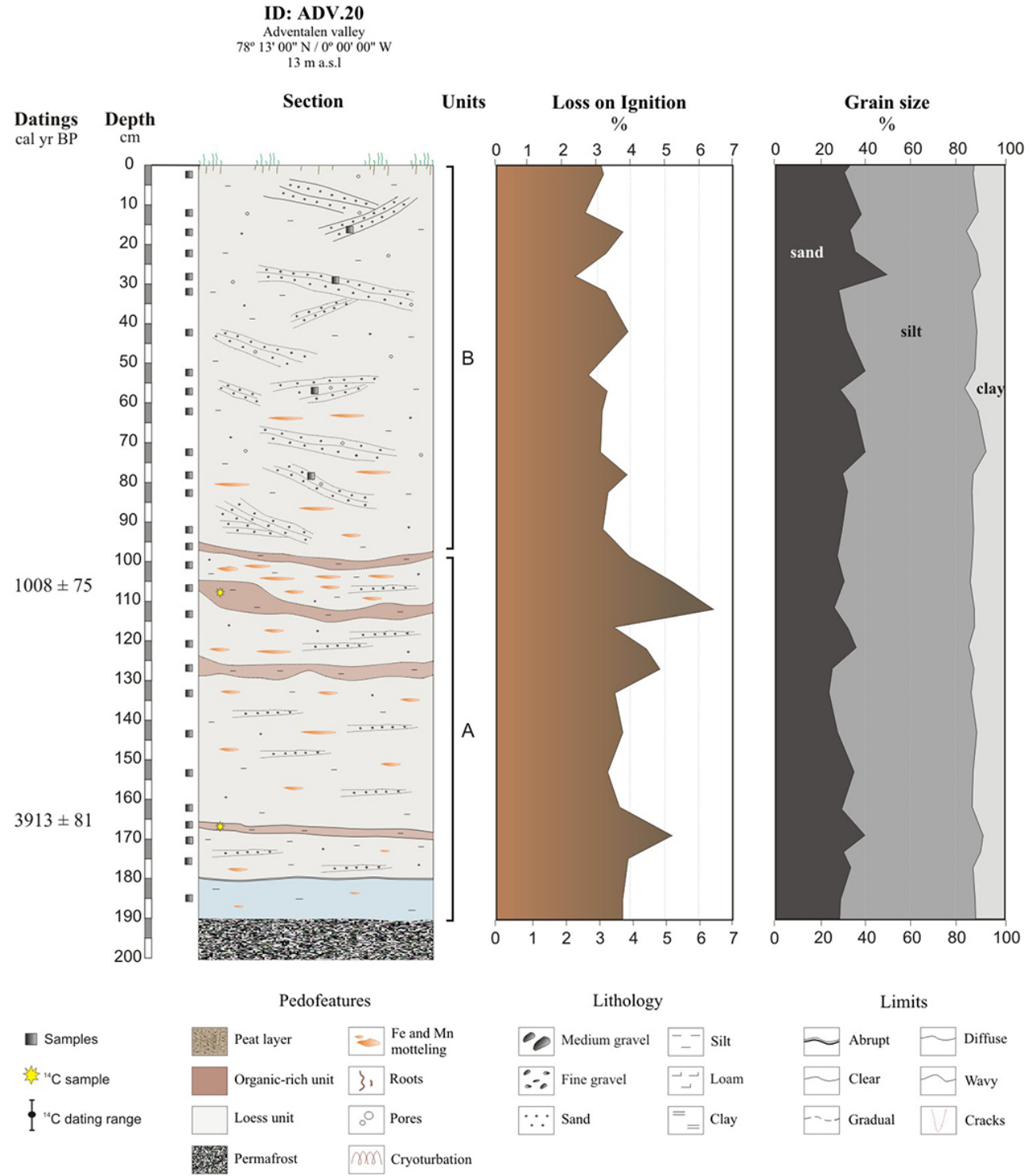

Figure 3. Lithostratigraphic section ADD.4 together with ${ }^{14} \mathrm{C}$ datings, LOI and grain size properties.

Table 1. AMS ${ }^{14} \mathrm{C}$ datings performed on the samples. Radiocarbon ages have been calibrated using the CALIB 7.0 program and the IntCal13 curve (Reimer et al., 2013).

\begin{tabular}{lclccc}
\hline Sample & Laboratory code & Dated material & Depth $(\mathrm{cm})$ & Conventional age (BP) & Calibrated age \\
\hline ADD4.1a & CNA1401 & Plant fragments & 115 & $3108 \pm 33$ & $3321 \pm 76$ \\
ADD4.1d & CNA1402 & Plant fragments & 85 & $3111 \pm 35$ & $3322 \pm 80$ \\
ADD4.3 & CNA1403 & Plant fragments & 81 & $3468 \pm 41$ & $3739 \pm 103$ \\
ADD4.11 & CNA1405 & Plant fragments & 73 & $2935 \pm 65$ & $3095 \pm 172$ \\
ADD4.14 & CNA1404 & Plant fragments & 65 & $2507 \pm 106$ & $2562 \pm 219$ \\
ADD4.18 & CNA1406 & Plant fragments & 57 & $3495 \pm 31$ & $3772 \pm 82$ \\
ADD4.26 & CNA1407 & Plant fragments & 50 & - & - \\
ADD4.27D & CNA1408 & Plant fragments & 20 & $583 \pm 28$ & $616 \pm 33$ \\
ADV20.3 & CNA1409 & Plant fragments & 165 & $3612 \pm 38$ & $3913 \pm 81$ \\
ADV20.7 & CNA1410 & Plant fragments & 105 & $1107 \pm 36$ & $1008 \pm 75$ \\
\hline
\end{tabular}




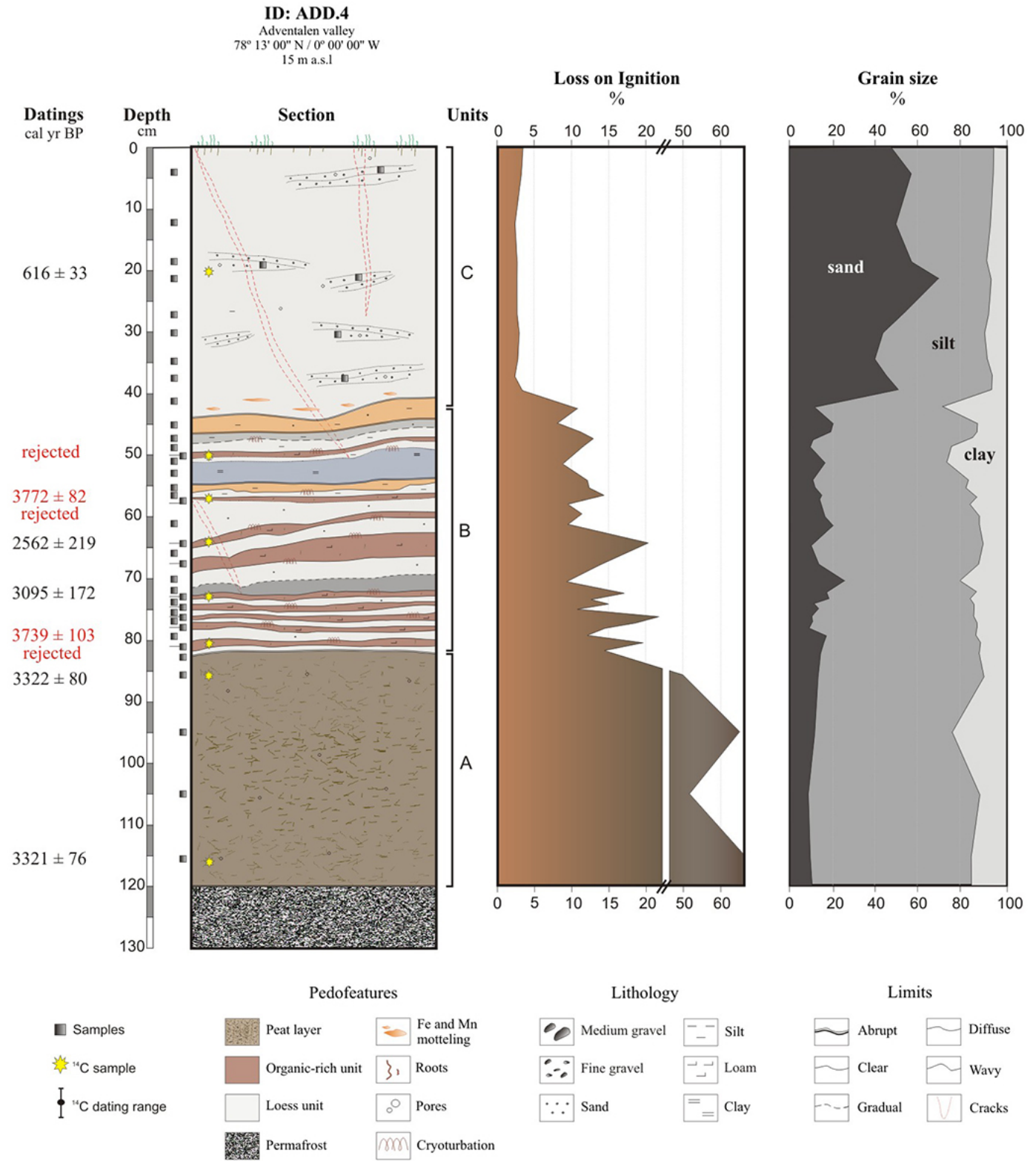

Figure 4. Lithostratigraphic section ADV.20 together with ${ }^{14} \mathrm{C}$ datings, LOI and grain size properties.

Table 2. Descriptive statistics of the studied elements (\% of LOI, sand, silt and clay) in sections ADD.4 and ADV.20. Significant differences are indicated by $*(p<0.05)$ and $* *(p<0.001)$; n.s. stands for "not significant" at a $p<0.05$.

\begin{tabular}{rrrrrrrr}
\hline & & M & Min & Max & SD & CV $(\%)$ & R: depth \\
\hline & LOI & 15.68 & 3.15 & 64.19 & 15.52 & 98.97 & $0.88^{* *}$ \\
ADD.4 $(N=38)$ & sand & 23.06 & 5.5 & 68.43 & 16.75 & 72.63 & $-0.63^{* *}$ \\
& silt & 63.08 & 25.49 & 80.94 & 12.33 & 19.54 & $0.76^{* *}$ \\
& clay & 13.83 & 5.38 & 25.33 & 5.46 & 39.47 & $0.35^{*}$ \\
\hline & LOI & 4 & 2.6 & 6.8 & 0.9 & 21.7 & $0.62^{* * *}$ \\
ADV.20 $(N=27)$ & sand & 32.7 & 27.6 & 47.6 & 4.3 & 13.2 & $-0.11^{\text {n.s }}$ \\
& silt & 55.4 & 42.1 & 60.3 & 3.9 & 7.1 & $0.21^{\text {n.s }}$ \\
& clay & 11.9 & 8.8 & 16.2 & 1.5 & 12.9 & $-0.08^{\text {n.s }}$ \\
\hline
\end{tabular}


Table 3. Descriptive statistics and correlation with the depth of the geochemical elements and trace elements analysed in the ADV.20 section. Significant differences at $p<0.05^{*}, p<0.001^{* *}$, n.s. not significant at a $p<0.05(N=10)$.

\begin{tabular}{lrrrrrr}
\hline & $\mathrm{M}$ & Min & Max & SD & CV(\%) & R: depth \\
\hline $\mathrm{SiO}_{2}$ & 73.09 & 70.45 & 74.28 & 1.10 & 1.51 & $-0.76^{* *}$ \\
$\mathrm{Al}_{2} \mathrm{O}_{3}$ & 11.25 & 10.68 & 11.72 & 0.35 & 3.07 & $0.68^{*}$ \\
$\mathrm{Fe}_{2} \mathrm{O}_{3}$ & 4.09 & 4.11 & 3.80 & 4.43 & 3.94 & $0.32^{\text {n.s }}$ \\
$\mathrm{K}_{2} \mathrm{O}$ & 2.24 & 2.14 & 2.31 & 0.05 & 2.37 & $0.20^{\text {n.s }}$ \\
$\mathrm{Na}_{2} \mathrm{O}$ & 1.68 & 1.53 & 1.82 & 0.10 & 5.83 & $-0.22^{\text {n.s }}$ \\
$\mathrm{MgO}$ & 0.70 & 0.65 & 0.76 & 0.03 & 4.74 & $0.50^{\text {n.s }}$ \\
$\mathrm{CaO}$ & 0.36 & 0.33 & 0.39 & 0.02 & 6.35 & $0.77^{* *}$ \\
$\mathrm{MnO}$ & 0.04 & 0.03 & 0.04 & 0.01 & 14.34 & $0.00^{\text {n.s }}$ \\
$\mathrm{P}_{2} \mathrm{O}_{5}$ & 0.12 & 0.07 & 0.17 & 0.03 & 26.93 & $0.14^{\text {n.s }}$ \\
$\mathrm{Cr}_{2} \mathrm{O}_{3}$ & 0.011 & 0.010 & 0.012 & 0.001 & 6.60 & $-0.05^{\text {n.s }}$ \\
$\mathrm{CIA}_{\mathrm{Ba}}^{72.44}$ & 71.39 & 73.30 & 0.65 & 0.89 & $0.71^{*}$ \\
$\mathrm{Ce}$ & 539 & 487 & 583 & 27.01 & 5.01 & $-0.17^{\text {n.s }}$ \\
$\mathrm{Cu}$ & 54.30 & 33 & 96 & 19.11 & 35.19 & $-0.06^{\text {n.s }}$ \\
$\mathrm{Nb}$ & 16.30 & 11 & 20 & 2.75 & 16.88 & $0.45^{\text {n.s }}$ \\
$\mathrm{Ni}$ & 45.70 & 7 & 22 & 4.62 & 31.42 & $0.54^{\text {n.s }}$ \\
$\mathrm{Sc}$ & 8.40 & 8 & 75 & 15.96 & 34.87 & $-0.23^{\text {n.s }}$ \\
$\mathrm{Sr}$ & 161.30 & 152 & 171 & 0.52 & 6.15 & $0.28^{\text {n.s }}$ \\
\hline
\end{tabular}

$(0.01 \%)$ were the less abundant. With regards to the trace elements, sediments were richer in $\mathrm{Ba}(539 \mathrm{ppm})$ and $\mathrm{Sr}$ (161.3 ppm) and poorer in Sc (8.4 ppm).

The CIA ranged from 71.39 to 73.30 , with an average of 72.44. The CV (\%) was higher in $\mathrm{P}_{2} \mathrm{O}_{5}$ (26.93) and $\mathrm{MnO}$ (14.34) and lower in $\mathrm{SiO}_{2}$ (1.51). A significant positive correlation of $\mathrm{CaO}$ and CIA with soil depth was detected as well as a significantly negative correlation in the case of $\mathrm{SiO}_{2}$ (Table 3). The distribution of the elements along this section is shown in Fig. 5. Regarding the CIA index, there was a clear decreasing trend from the bottom layers upwards, though it increased sharply from $65 \mathrm{~cm}$ depth to the surface (Fig. 5c).

\section{Discussion}

Previous research has already identified a large number of periglacial landforms in the landscape of Adventdalen - such as pingos, palsas, sorted circles and ice wedges - which are indicative of permafrost conditions in the area (Humlum et al., 2003). In both margins of Adventelva, where the relief is relatively flat, polygonal networks of different size and morphologies are distributed. These areas hide a complex internal sedimentary structure of Holocene age (Härtel, 2011).

\subsection{Palaeoenvironmental evolution in Adventdalen floor}

The research presented in this paper focuses on lower Adventdalen, an area that has been ice-free since the beginning of the Holocene (Lønne and Nemec, 2004). Ice-free areas in Svalbard experienced significant environmental changes dur-

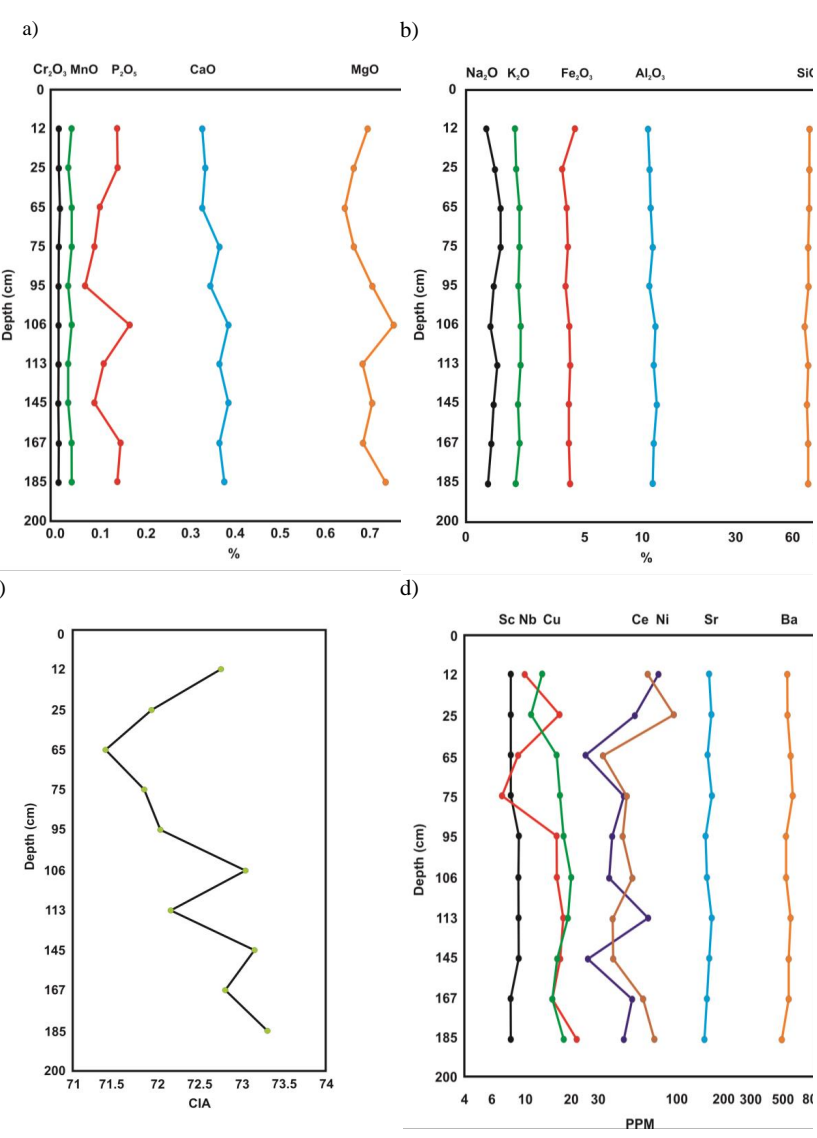

Figure 5. Profile distribution of the geochemical elements studied.

ing the middle and late Holocene (Birks, 1991; Svendsen and Mangerud, 1997; Humlum, 2005).

The sedimentological characteristics of two long sedimentary sequences located in two areas where ice-wedge polygonal terrains are widespread morphological features have been studied. The bases of these sequences correspond to the level of the frozen ground at the beginning of September 2011. Permafrost was found at $1.9 \mathrm{~m}$ in the southern site ADV.20 and at $1.3 \mathrm{~m}$ in the northern site ADD.4. Apart from differences in aspect, the presence of a peat layer in ADD. 4 contributed to thermally insulating the ground and was favourable for a permafrost table closer to the surface than in ADV.20, where no peat layer was observed. The two exposures include sediments deposited from the middle to the late Holocene transition period until the present day. According to the basal datings, ADD.4 encompasses the last $3.3 \mathrm{ka} \mathrm{BP}$ and ADV.20 the last $3.9 \mathrm{ka} \mathrm{BP}$.

Section ADD.4 shows two very different sedimentological environments separated by a transition period, denoting that significant environmental changes have occurred in this area over the last three millennia. The stabilization of geomorphic activity at the distal part of alluvial fans in contact with Adventelva around $3.6 \mathrm{ka} \mathrm{BP}$ was favourable for peat formation in these areas (Jeppesen, 2001; Härtel, 
2011). According to data obtained in ADD.4, the combination of climate and topographical conditions in the northern margin of the river continued to be favourable to peat development until ca. $3.3 \mathrm{kaBP}$. The two basal ${ }^{14} \mathrm{C}$ dates in ADD.4 yielded similar ages despite being vertically separated by $30 \mathrm{~cm}$ (3322 \pm 80 years and $3321 \pm 76$ years respectively). These dates fit within the range of 2.8-3.4 ka BP reported in other sites of Adventdalen for the formation of this widespread thick peat layer (Härtel, 2011). A very rapid peat growth is assumed during this period, probably driven by a warmer climate regime. Favourable climate conditions for peat growth in the high Arctic are strongly controlled by temperatures and soil moisture content (Ellis and Rochefort, 2006). Evidence from marine records indicates warmer temperatures in Svalbard from the beginning of the Holocene until ca. $3.5 \mathrm{ka} \mathrm{BP}$ due to increased inflow of warm Atlantic water with summer sea surface temperatures probably $1-3{ }^{\circ} \mathrm{C}$ warmer than today (Salvigsen et al., 1992; Salvigsen, 2002).

Around $85 \mathrm{~cm}$ depth there is a clear change, with a sharp decrease in the organic matter content (LOI drops from $>50 \%$ to $15 \%$ ). A sample from this level was radiocarbondated to $3739 \pm 103$ years BP. However, this age is too old with respect to the chronological sequence and should be rejected. According to the lower (3322 \pm 80 years BP) and upper ${ }^{14} \mathrm{C}$ datings $(3095 \pm 172$ years $\mathrm{BP})$ this change with significant environmental consequences in the area must have occurred around $3.2 \mathrm{kaBP}$. This time frame is consistent with other records in Svalbard that indicate a deterioration of the warm conditions: evidence of glacier expansion starting at $3 \mathrm{ka} \mathrm{BP}$ until $2.5 \mathrm{ka} \mathrm{BP}$ has been inferred from proglacial lake sediments (Svendsen and Mangerud, 1997) and fjords in western Svalbard (Kempf et al., 2013).

Climate variability and possible modifications in the local geomorphological setting must be taken into account when interpreting sedimentological changes in site ADD.4. The changing fluvial activity in Adventelva during the last millennia may have entailed variations in the deflation processes reaching ADD.4 since this fluvial braided system constitutes the source of the uppermost sediments of this sequence, which are interpreted as loess based on their particle size. Bryant (1982) already described these deposits as loess. Variations in the source of the sediments with respect to the location of the site ADD. 4 may have been favourable for peat formation or aeolian deposition. However, the fact that other regional proxies point to a change in the climate conditions prevailing in Svalbard until ca $3 \mathrm{kaBP}$ (Svendsen and Mangerud, 1997, Kempf et al., 2013) suggests that this change to less dense vegetation cover and increased aeolian deposition may also be connected to climate variability. From 3 ka BP onwards climate conditions became progressively more favourable to tundra-type vegetation, with no peat development, less grass cover and increasing mineral sedimentation. However, this long-term pattern was divided into a series of periods in which soil formation alternates with aeolian sedimentation. A similar sedimentologi- cal pattern is observed in ice-wedge polygons between 2.75 and $2.35 \mathrm{ka} \mathrm{BP}$ in the eastern Canadian Arctic (Fortier et al., 2006). Probably, in Svalbard these phases were driven by changing moisture conditions. Marine records show changing patterns in ocean circulation in the North Atlantic region during this period (Skirbekk et al., 2010; Moros et al., 2012). These changes must have brought about environmental shifts in the terrestrial ecosystem. Birks et al. (1991) also detected a change in the vegetation zones around $2.5 \mathrm{ka} \mathrm{BP}$ due to increasing climatic severity. A change towards declining sedimentation rates is also recorded in proglacial lakes around 2.4-2.5 ka BP (Svendsen and Mangerud, 1997).

However, the samples at 50 and $60 \mathrm{~cm}$ depth did not yield consistent ${ }^{14} \mathrm{C}$ ages and, therefore, an accurate calendar for the moment at which aeolian deposition became dominant at ADD.4, with no development of organic-rich soils, can not be provided. For this specific site we can only assume that it took place after 2.5 and before $0.6 \mathrm{ka} \mathrm{BP}$. Since then, aeolian processes have deposited a $40-45 \mathrm{~cm}$ thick loess cover on this glaciofluvial terrace, where ice-wedge polygons are, today, well-developed.

In the southern margin of Adventelva the thick aeolian deposit covering the lowest terraces has buried the coarser sediments of the Todalen alluvial fan. Deeper levels in ADV.20 show a rather homogeneous lithostratigraphical sequence with little variation in terms of grain size and organic matter content. Only four levels were identified with slightly higher organic matter percentages but without significant grain size changes. The basal layers for ADV.20 yielded an age of $3913 \pm 81$ years. This date may appear to be too early since the widespread peat layer dated to $2.8-3.4 \mathrm{ka} \mathrm{BP}$ at other sites from Adventdalen was not found in the first $1.9 \mathrm{~m}$ depth examined in this section. Uncertainties in ${ }^{14} \mathrm{C}$ dating are common in this area - and have already been described in other Quaternary chronological studies - due to the presence of Tertiary coal strata contaminating the samples, thus providing older ages than expected (Humlum et al., 2005; Härtel, 2011).

In section ADV.20 a sample at $105 \mathrm{~cm}$ depth yielded an age of $1008 \pm 75$ years, which suggests a deposition rate of $1 \mathrm{~mm} \mathrm{yr}^{-1}$ for the upper sediments. An increase of the loess accumulation rates has been inferred for the last millennium in parallel to colder and possibly windier and dryer conditions in Svalbard (Härtel, 2011). A windier climate must have also entailed higher evaporation rates, thus reinforcing the effect of aeolian processes. This colder climate regime was more intense during the winter season (Divine et al., 2011), and particularly between AD 1500 and the end of 1800 (Isaksson et al., 2005). This cooling was favourable for widespread glacier growth in Svalbard during the Little Ace Age (LIA), particularly since the 13-14th centuries (Svendsen and Mangerud, 1997; Hald et al., 2001; Humlum et al., 2005). In other areas of the high North Atlantic region, loess deposition was also more intense during the LIA, such as in Iceland between 0.6 and $0.1 \mathrm{ka} \mathrm{BP}$ (Jackson et al., 2005). 
The increase of the mean annual temperatures recorded after the LIA as well as the significant warming of the last decades (Humlum et al., 2011a) led to important environmental changes in the terrestrial ecosystem in Svalbard (Lønne and Lyså, 2005). However, the impact of these higher temperatures is not detected in the sedimentary record of the two studied sections. The pattern of the prevailing sedimentological processes is the same as during the LIA, with high loess deposition enhanced by the sparse vegetation cover in these areas.

\subsection{Site-specific controls on sedimentological processes}

Significant differences in the studied variables are observed between the two sections, which may be attributable to diverse environmental responses in both local settings. ADV.20 section is located on a south-facing bank of the river, contrary to ADD.4 that is located on a northern slope exposition. The aeolian cover on the southern bank is constituted by sediments $40-45 \mathrm{~cm}$ thick, while in the northern site this layer can reach a thickness of 1.5-2 m. A deposition rate of $1 \mathrm{~mm} \mathrm{yr}^{-1}$ has been calculated for the upper aeolian sediments in ADV.20, which is in agreement with Optically stimulated luminescence (OSL) datings from neighbouring sites (Härtel, 2011). Therefore, loess sedimentation rates in the lowest terraces of the southern side of Adventdalen are much higher than on the northern side.

Furthermore, the fact that ADV.20 had significantly higher percentages of sand content and ADD.4 showed larger proportions of silt content may be evidence of the different sources and/or energy of transport prevailing in both areas. Aeolian transport is not a uniform process and can occur in different forms depending on the source area characteristics and transport height and distance (Vandenberghe, 2013). Changes in wind strength and/or direction are very likely responsible for the different grain size transport in loess environments (Zech et al., 2008). This pattern is even more significant in braided systems, where variations in fluvial dynamics through time may condition changes in the size of the particles mobilized and subsequently deposited in the surrounding areas. On a local scale, wind circulation is very complex especially in irregular topographic areas, which can increase or decrease wind intensity (Jonassen et al., 2012). Previous work on loess deposits observed that local wind systems in valleys can be important in the formation of aeolian deposits (Sun and Liu, 2000).

Indeed, slope position and exposure have implications on the process of soil formation in loess areas (Finke, 2012; Finke et al., 2013). On a microscale level this fact has implications on soil development and on the degree of surface vegetation cover. Weak soil formation and sparse vegetation cover facilitate sediment transport (Vandenberghe, 2013), enhanced by favourable wind circulation. These environmental conditions must have facilitated the transport and deposition of fine-grained sediments from the Adventelva floodplain, especially in the ADV.20 area with a higher percentage of sands in this sequence.

The correlations between soil depth and LOI, silt and clay in the ADD. 4 profile were significantly positive, while sand showed a significant negative correlation. Regarding the ADV.20 section, only LOI had a significant positive correlation. No significant correlation was observed for the other variables. These results showed higher LOI values at the bottom than at the top of both section (Figs. 3, 4). However, in ADD.4, the positive significant correlation in silt and clay showed that they were predominant in the bottom layers, while sand was common in the top layers. In relation to ADV.20, no correlations were observed. The CV (\%) of LOI, sand, silt and clay was higher in ADD.4 showing that variability of sediment organic matter and texture was higher than in ADV.20. Thus, grain size variations reflected the changes between accumulation rate and pedogenesis in the period after the deposition (Huang et al., 2012).

\subsection{Geochemical properties of the sediments}

The major element concentration in loess and paleosols reflects their properties directly from their source properties, but also their evolution after deposition (Jahn et al., 2001). Silica and $\mathrm{Al}_{2} \mathrm{O}_{3}$ were the most common minerals in the ADV.20 profile, denoting the presence of aluminosilicate minerals such as micas and feldspars (Ujvari et al., 2008). The predominance of these elements in loess deposits was observed in previous studies in similar regional settings (Drewnik et al., 2014; Gallet et al., 1998). The variability of the studied geochemical elements showed little variation along the section. This is indicative of no major changes in the pedogenic processes at this site, as well as stability in the source of the sediments deposited in ADV.20 during the last millennia.

Regarding the weathering processes, high values of CIA are related to strong chemical weathering, while low values are connected with weak soil formation (Zech et al., 2008). Previously, Gallet et al. (1998) observed in a meta analysis of loess deposits in several parts of the world that CIA values were in the range of 50-70. The authors concluded that these deposits had a similar alteration history and were subjected to moderate weathering. For cold-climate regions, Daviel et al. (2011) inferred an average value of 74.4 in a paleosol located in central Yukon; these authors propose that values near 75 show a considerable proportion of primary minerals converted into clay minerals. In Siberia, Zech et al. (2008) identified values of CIA $>63$ that they interpreted as being related to intense weathering processes. For this site in Svalbard, the average of CIA gives a value of 72.44. Taken into account the limited literature on these topics, weathering at the ice-wedge polygon terrain in Adventdalen can be considered moderate or slightly high. The variability of CIA was reduced ( $89 \%$ of CV), suggesting that the chemical alteration was almost homogeneous along all of the profile, confirming 
small variations in pedogenic intensity during the time span covered in this section. However, a significant positive correlation with depth is detected, which suggests that weathering processes were slightly more active in the sediments located in the deeper layers. In our case, the high levels of CIA in the bottom layers may be related with the presence of higher soil organic matter concentrations during periods of weak soil formation.

In ADV.20, on average, the most common trace element was Ba. Previous work on loess deposits also observed that there was a higher Ba relative to other trace elements (Gallet et al., 1998; Jahn et al., 2001; Varga et al., 2011). In this case, the high content of $\mathrm{Ba}$ in ADV.20 can be strongly influenced by the deposition of marine aerosols from the adjacent sea and an in situ enrichment due the higher mobility of other elements (Zach et al., 2008). The distribution of Ba can be also related to the intensity of the soil formation. The accumulation of $\mathrm{Ba}$ is supported by illuviation including the formation of new clay minerals, variation of redox conditions and translocation of elements and minerals (Galovic et al., 2011). The low variability of this element across the profile is an evidence that weathering process and soil formation were not variable (Bokhorst et al., 2009).

\subsection{Implications for ice-wedge polygon terrains}

In Adventdalen, the lowest glaciofluvial terraces covered by loess close to the Adventelva braided plain are the environments where ice-wedge polygon terrains are more abundant. The fact that, today, the process of cracking in ice-wedge terrain in Svalbard is active under present-day climate conditions (Christiansen, 2005; Watanabe et al., 2012a, 2013) suggests that these flat areas covered at present by a thick layer of aeolian sediments constitute very appropriate environments for the development of ice wedges.

Studies in other areas of the high Arctic have shown that the development of ice-wedge polygon terrains during the Holocene is strongly conditioned by the characteristics of the sediments as well as by climate variability (Fortier and Allard, 2004; Fortier et al., 2006). The properties of the host sediments may have conditioned the geometry of the polygons: homogeneous host materials generate hexagonal intersections while heterogeneous sediments form orthogonal intersections (Lachenbruch, 1962; Härtel, 2011).

In Svalbard, for the southern Adventdalen area, Härtel (2011) has detected the presence of a segregated ice layer marking a transient layer at the level of the peat layer. This indicates that permafrost was present at the time that peat was forming. The formation of permafrost in a peaty environment may also act as a feedback process to maintain the permanent frozen conditions in the ground thanks to the insulator effect of the overlying peat layer. This, in turn, is also favourable for ice-wedge formation. Therefore, one likely interpretation is that, in the northern terrace, ice wedges could have started developing when peat was forming at $3.3 \mathrm{kaBP}$. This process continued throughout the late Holocene and was reinforced particularly during the last millennium, with the environmental shift towards prevailing aeolian deposition and thick loess accumulation. Indeed, colder conditions, particularly in winter (Divine et al., 2011), must have reinforced the process of ice-wedge formation.

\section{Conclusions}

In this paper, two sedimentary sequences located in the northern and southern glaciofluvial terraces of Adventelva where ice-wedge polygonal networks are abundant have been examined. The northern section (ADD.4) is much more heterogeneous than the southern one (ADV.20), where sediments show little variations in grain size or organic matter content. Climate conditions must have been decisive to imprint these changes on the sedimentation processes, together with the geomorphological setting, which may also explain the differences observed between the two sections.

In ADD. 4 the existence of very different lithostratigraphic units must be a consequence of environmental changes in this periglacial environment during the last three millennia. A period of widespread peat formation in Adventdalen took place until $3.3 \mathrm{ka} \mathrm{BP}$. This period of geomorphic stability was driven probably by warmer conditions than today. After $3.2 \mathrm{ka} \mathrm{BP}$ a phase with alternating soil formation and loess deposition took place, subsequently changing to a period of predominance of aeolian deposition. Unfortunately, our records do not allow us to establish a precise timing for this change (between 2.5 and $0.6 \mathrm{ka} \mathrm{BP}$ ), although other studies indicate that this pattern intensified during the last millennium (Härtel, 2011). In both sections a thick loess cover constitutes the uppermost sediments, ranging from 40 to $45 \mathrm{~cm}$ thickness in the northern site to $1-2 \mathrm{~m}$ on the southern bank of Adventelva. Here, the upper $1 \mathrm{~m}$ of loess sediments were deposited during the last $1 \mathrm{ka}$. The post-LIA warming has not promoted any significant change in the sedimentological processes prevailing in both areas.

In the eastern Canadian Arctic, syngenetic ice-wedge polygons developed in windblown silt and organic sediments during the late Holocene (Fortier and Allard, 2004). In the Adventdalen floor, recent studies suggest that the formation of ice wedges could have started when peat was forming (Härtel, 2011). Therefore, the landscape of the present-day ice-wedge polygonal terrains may have its origin in the transition from the middle to late Holocene; gradually, as environmental conditions shifted to prevailing aeolian deposition, the process of ice-wedge formation became more intense in the lowest glaciofluvial terraces in Adventdalen.

Soil organic matter content and grain size differences between ADD.4 and ADV.20 suggest that their development was dependent on the topographical and geomorphological characteristics at microsite level. The location of the two sites conditioned soil formation and/or aeolian deposition 
on both banks of Adventelva where ice-wedge polygons are distributed. Regarding the geochemical composition at site ADV.20, the most abundant major minerals were $\mathrm{SiO}_{2}$ and $\mathrm{Al}_{2} \mathrm{O}_{3}$, and $\mathrm{Ba}$ the was the trace element found in higher amounts. However, the magnitude of the changes detected in the studied variables is generally small. This fact can be interpreted as a consequence of little variation in the intensity of the pedogenic processes at this site as well as in the sediment sources prevailing in the area during the late Holocene.

Acknowledgements. The first author thanks the Agency for the Management of University and Research Grants (AGAUR) of Catalonia and the AXA Research Fund for funding a postdoctoral fellowship, during which this paper was written. This research has been supported by the Portuguese Science Foundation (FCT) under the project ANAPOLIS (PTDC/CTE-SPA/99041/2008). We would like to acknowledge the logistic support in field activities provided by The University Centre in Svalbard through Hanne Christiansen as well as Adriane Machado (University of Coimbra) for carrying out the XRF measurements.

Edited by: A. Navas

\section{References}

Allen, C. E., Darmody, R. G., Thorn, C. E., Dixon, J. C., and Schlyster, P.: Clay mineralogy, chemical weathering and landscape evolution in Artic-Alpine Sweden, Geoderma, 99, 277294, 2001.

Birks, H. H.: Holocene vegetational history and climatic change in west Spitsbergen - plant macrofossils from Skardtjørna, an Arctic lake, Holocene, 1, 209-218, 1991.

Bokhorst, M. P., Beets, C. J., Markovic, S. B., Gerasimenko, N. P., Matviishina, Z. N., and Frenchen, M.: Pedo-chemical climate proxies in Late Pleistocene Serbian-Ukrainian loess sequences, Quatern. Int., 198, 113-123, 2009.

Bryant, Y. D.: Loess deposits in Lower Adventdalen, Spitsbergen, Polar Res, 2, 93-103, 1982.

Burn, C. R.: Implications for paleoenvironmental reconstruction of recent ice-wedge development at Mayo, Yukon territory, Permafrost Periglac., 1, 3-14, 1990.

Christiansen, H. H.: Thermal regime of ice-wedge cracking in Adventdalen, Svalbard, Permafrost Periglac., 16, 87-98, 2005.

Christiansen, H. H. and Humlum, O.: Interannual variations in active layer thickness in Svalbard, Proceedings of the Ninth International Conference on Permafrost, University of Alaska, Institute of Northern Engineering Fairbanks, USA, 257-262, 2008.

Christiansen, H. H., Etzelmüller, B., Isaksen, K., Juliussen, H., Farbrot, H., Humlum, O., Johansson, M., Ingeman-Nielsen, T., Kristensen, L., Hjort, J., Holmlund, P., Sannel, A., Sigsgaard, C., Åkerman, H. J., Foged, N., Blikra, L., Pernosky, M. A., and Ødegård, R. S.: The thermal state of permafrost in the Nordic area during the International Polar Year 2007-2009, Permafrost Periglac., 21, 156-181, 2010.
Daviel, A., Sanborn, P., Tarnocai, C., and Smith, C. A.: Clay mineralogy and chemical properties of argilic horizons in central Yukon paleosols, Can. J. Soil. Sci., 91, 83-93, 2011.

Divine, D., Isaksson, E., Martma, T., Meijer, H. A., Moore, J., Pohjola, V., van de Wal, R. S., and Godtliebsen, F.: Thousand years of winter surface air temperature variations in Svalbard and northern Norway reconstructed from ice-core data, Polar Res., 30, 73-79, 2011.

Drewnik, M., Skiba, M., Szymanski, W., and Zyla, M.: Mineral composition vs. soil forming in loess soils a case study from Krakow (Southern Poland), Catena, doi:10.1016/j.catena.2014.02.012, 2014.

Egli, M., Dahms, D., and Norton, K.: Soil formation rates on silicate parent material in alpine environments: Different approaches different results?, Geoderma, 213, 320-333, 2014.

Ellis, C. J. and Rochefort, L.: Long-term sensitivity of a High Arctic wetland to Holocene climate change, J. Ecol., 94, 441-454, 2006.

Finke, P. A.: Modelling the genesis of livisols as a function of topographic position in loess material, Quatern. Int., 265, 3-17, 2012.

Finke, P. A., Vanwalleghem, T., Opolot, E., Poesen, J., and Deckers, S.: Estimating the effect of tree uprooting on variation of soil horizon depth by confronting pedogenetic simulations to measurements in a Belgian loess area, J. Geophys. Res., 118, 1-16, 2013.

Førland, E. J., Rasmus, B., Hanssen-Bauer, I., Haugen, J. E., and Skaugen, T. E.: Temperature and precipitation development at Svalbard 1900-2100, Adv. Meteorol., 893790, doi:10.1155/2011/893790, 2011.

Fortier, D. and Allard, M.: Late Holocene syngenetic icewedge polygons development, Bylot Island, Canadian Arctic Archipelago, Can. J. Earth. Sci., 41, 997-1012, 2004.

Fortier, D. and Allard, M.: Frost-cracking conditions, Bylot Island, eastern Canadian Arctic archipelago, Permafrost Periglac., 16, 145-161, 2005.

Fortier, D., Allard, M., and Pivot, F.: A late-Holocene record of loess deposition in ice-wedge polygons reflecting wind activity and ground moisture conditions, Bylot Island, eastern Canadian Arctic, Holocene, 16, 635-646, 2006.

Forwick, M. and Vorren, T. O.: Stratigraphy and deglaciation of the Isfjorden area, Spitsbergen, Norw. J. Geol., 90, 163-179, 2010.

French, H.: The periglacial environment, Wiley, West Sussex, England, Third Edition, 2007.

Gallet, S., Jahn, B., Van Vliet-Lanoë, B., Dia, A., and Rosello, E.: Loess geochemistry and its implications for particle origin and composition of the upper continental crust, Earth Planet. Sc. Lett., 156, 157-172, 1998.

Galovic, L., Frechen, M., Peh, Z., Durn., and Halamic, J.: Loess/palaeosol section in Sarengrad, Croatia - a qualitative discussion on the correlation of geochemical and magnetic susceptibility data, Quatern. Int., 240, 22-34, 2011.

Grinsted, A., Moore, J. C., Pohjola, V., Martma, T., and Isaksson, E.: Svalbard summer melting, continentality, and sea ice extent from the Lomonosovfonna ice core, J. Geophys. Res., 111, doi:10.1029/2005JD006494, 2006.

Hagen, J. O., Liestøl, O., Roland, E., and Jørgensen, T.: Glacier atlas of Svalbard and Jan Mayen, Norsk Polarinst, Map 129, 1993.

Hald, M., Dahlgren, T., Olsen, T., and Lebesbye, E.: Late Holocene palaeoceanography in Van Mijenfjorden, Svalbard, Polar Res., 20, 23-35, 2001. 
Hall, K., Thorn, C. E., Matsuoka, N., and Prick, A.: Weathering in cold regions: some thoughts and perspectives, Prog. Phys. Geog., 26, 577-603, 2002.

Hall, K.: Rock temperatures and implications for cold region weathering. I: New data from Viking valley, Alexander Island, Antarctica, Permafrost Periglac., 8, 69-90, 1997.

Hall, K.: Evidence for freeze-thaw events and their implications for rock weathering in Northern Canada, Earth. Surf. Proc. Land., 29, 43-57, 2004.

Härtel, S.: Formation and dynamics of Holocene ice-wedge polygons in Lower Adventdalen, Svalbard, M. S. thesis, University of Svalbard, Norway, 114 pp., 2011.

Holmgren, S., Bigler, C., Ingolfsson, O., and Wolfe, A. P.: The Holocene-Anthropocene transition in lakes of western Spitsbergen, Svalbard (Norwegian High Arctic): Climate change and nitrogen deposition, J. Paleolimnol., 43, 393-412, 2010.

Huang, C. Q., Zhao, W., Li, F. Y., Tan, W. F., and Wang, M. K.: Mineralogical and pedogenetic evidence for paleoenvironmental variations during the Holocene on the Loess Plateau, China, Catena, 96, 49-56, 2012.

Humlum, O.: Holocene permafrost aggradation in Svalbard. Geological Society of London Special Publication, 242, 119-129, 2005.

Humlum, O., Instanes, A., and Sollid, J.L.: Permafrost in Svalbard: a review of research history, climatic background and engineering challenges, Polar Res, 22, 191-215, 2003.

Humlum, O., Elberling, B., Hormes, A., Fjordheim, K., Hansen, O. H., and Heinemeier, J.: Late-Holocene glacier growth in Svalbard, documented by subglacial relict vegetation and living soil microbes, Holocene, 15, 396-407, 2005.

Humlum, O., Solheim, J. E., and Stordahl, K.: Spectral analysis of the Svalbard temperature record 1912-2010, Advances in Meteorology, 175296, doi:10.1155/2011/175296, 2011a.

Humlum, H., Solheim,, J. E., and Stordahl, K.: Identifying natural contributions to late Holocene climate change, Global Planet. Change, 79, 145-156, 2011b.

Isaksson, E., Divine D., Kohler, J., Martma, T., Pohjola, V., Motoyama, H., and Watanabe, O.: Climate oscillations as recorded in Svalbard ice core $\delta^{18} \mathrm{O}$ records between AD 1200 and 1997, Geogr. Ann. A., 87, 203-214, 2005.

Jackson, M. G., Oskarsson, N., Trønnes, R. G., McManus, J. F., Oppo, D. W., Grönvold, K., Stanley R. Hart, S. R., and Sachs, J. P.: Holocene loess deposition in Iceland: Evidence for millennial-scale atmosphere-ocean coupling in the North Atlantic, Geology, 33, 509-512, 2005.

Jahn, B. M., Gallet, S., and Han, J.: Geochemistry of the Xining, Xifeng and Jixian sections, Loess Plateau of China: eolian dust provenance and paleosol evolution during the last $140 \mathrm{ka}$, Chem. Geol., 178, 71-94, 2001.

Jeppesen, J. W.: Ice wedges and host sediments as palaeoclimatic indicators in central Spitsbergen, Svalbard (in Danish), M.S. thesis, University of Copenhagen, Denmark, 101 pp., 2001.

Jonassen, M. O., Olafsson, H., Reuder, J., and Olseth, J. A.: Multiscale variability winds in the complex topography of southwestern Norway, Tellus, 64, 11962, doi:10.3402/tellusa.v64i0.11962, 2012.

Kempf, P., Forwick, M., Laberg, J. S., and Vorren, T. O.: Late Weichselian - Holocene sedimentary palaeoenvironment and glacial activity in the high-Arctic van Keulenfjorden, Spitsbergen, Holocene, 23, 1605-1616, 2013.

Lachenbruch, A. H.: Mechanics of thermal contraction cracks and ice-wedge polygons in permafrost, Geol. Soc. Am., 70, 1-68, 1962.

Liest $\varnothing 1$, O.: Pingos, springs and permafrost in Spitsbergen, Norsk Polarinst. Skri., 1975, 7-29, 1976.

Liest $\varnothing 1$, O.: The glaciers in the Kongsfjorden area, Spitsbergen, Norsk Geogr. Tidsskr., 42, 231-238, 1988.

Lønne, I. and Lyså, A.: Deglaciation dynamics following the Little Ice Age on Svalbard: implications for shaping of landscapes at high latitudes, Geomorphology, 72, 300-319, 2005.

Lønne, I. and Nemec, W.: High-arctic fan delta recording deglaciation and environmental disequilibrium, Sedimentology, 51, 553589, 2004.

Mackay, J. R.: Thermally induced movements in ice-wedge polygons, western arctic coast: a long-terms study, Geogr. Phys. Quatern., 54, 41-68, 2000.

Major, H., Haremo, P., Dallmann, W. K., and Andresen, A.: Geological Map of Svalbard 1, 100,000, Norsk Polarinst, Map C9G Adventdalen, 31-32, 2001.

Matsuoka, N. and Murton, J.: Frost weathering: recent advances and future directions, Permafrost Periglac., 19, 195-210, 2008.

Moberg, A., Sonechkin, D. M., Holmgren, K., Datsenko, N. M., and Karlenm, W.: Highly variable Northern Hemisphere temperatures reconstructed from low- and high-resolution proxy data, Nature, 433, 613-617, 2005.

Moros, M., Jansen, E., Oppo, D.W., Giraudeau, J., and Kuijpers, A.: Reconstruction of the late-Holocene changes in the Sub-Arctic Front position at the Reykjanes Ridge, north Atlantic, Holocene, 22, 877-886, 2012.

Nesbitt, H. W., and Young, G. M.: Early Proterozoic climates and plate montions inferred from major element chemistry of lutites, Nature, 229, 715-717, 1982.

Opel, T., Dereviagin, A. Yu., Meyer, H., Schirrmeister, L., and Wetterich, S.: Palaeoclimatic information from stable water isotopes of Holocene ice wedges on the Dmitrii Laptev Strait, northeast Siberia, Russia, Permafrost Periglac., 22, 84-100, 2011.

Pina, P.: Polygonal pattern analysis on Mars based on Svalbard analogues, Proceedings of the V Iberian Conference of the International Permafrost Association, University of Barcelona, in press, 2014.

Reimer, P. J., Bard, E., Bayliss, A., Beck, J. W., Blackwell, P. G., Bronk Ramsey, C., Buck, C. E., Cheng, H., Edwards, R. L., Friedrich, M., Grootes, P. M., Guilderson, T. P., Haflidason, H., Hajdas, I., Hatté, C., Heaton, T. J., Hoffmann, D. L., Hogg, A., Hughen, K. A., Kaiser, K. F., Kromer, B., Manning, S. W., Niu, M., Reimer, R. W., Richards, D. A., Scott, E. M., Southon, J. R., Staff, R. A., Turney, C. S. M., and van der Plicht, J.: IntCal13 and Marine13 radiocarbon age calibration curves 0-50,000 years cal BP, Radiocarbon, 55, 1869-1887, 2013.

Salvigsen, O.: Radiocarbon-dated Mytilus edulis and Modiolus modiolus from northern Svalbard: climatic implications, Norsk Geogr Tidsskr, 56, 56-61, 2002.

Salvigsen, O., Forman, S. L., and Miller, G. H.: Thermophilous molluscs on Svalbard during the Holocene and their paleoclimatic implications, Polar Res., 11, 1-10, 1992. 
Saraiva, J., Lousada, M., Pina, P., Bandeira, L., and Vieira, G.: Geometric and topologic characterization of periglacial polygonal networks in Adventdalen, Svalbard, Norway, EGU General Assembly, Vienna, Austria, 22-27 April 2012, EGU2012-10818-1, 2012.

Schwamborn, G., Meyer, H., Fedorov, G., Schirrmeister, L., and Hubberten, H. W.: Ground ice and slope sediments archiving Late Quaternary paleoenvironment and paleoclimate signals at the margins of Elgygytgyn Crater, NE Siberia, Quaternary Res., 66, 259-272, 2006.

Skirbekk, K., Klitgaard-Kristensen, D., Rasmussen, T. L., Koç, N., and Forwick., M.: Holocene climate variations at the entrance to a warm Arctic fjord: evidence from Kongsfjorden trough, Svalbard, in: Fjordic Depositional Systems and Archives, Geological Society of London Special Publication, 344, 289-304, 2010.

Snyder, J. A., Werner, A., and Miller, G. H.: Holocene cirque glacier activity in western Spitsbergen, Svalbard: sediment records from proglacial Linnévatnet, Holocene, 10, 555-563, 2000.

Sørbel L. and Tolgensbakk, J.: Ice-wedge polygons and solifluction in the Adventdalen area, Spitsbergen, Svalbard, Norsk Geogr. Tidsskr., 56, 62-66, 2002.

Svendsen, J. I. and Mangerud, J.: Holocene glacial and climatic variations on Spitsbergen, Svalbard, Holocene 7, 45-57, 1997.

Sun, J. M. and Liu, T.: Multiple origins and interpretations of magnetic susceptibility signal in Chinese wind-blow sediments, Earth Planet. Sc. Lett., 180, 287-296, 2000.

Sundqvist, H. S., Zhang, Q., Moberg, A., Holmgren, K., Körnich, H., Nilsson, J., and Brattström, G.: Climate change between the mid and late Holocene in northern high latitudes - Part 1: Survey of temperature and precipitation proxy data, Clim. Past, 6, 591-608, doi:10.5194/cp-6-591-2010, 2010.

Thorn, C. E., Darmody, R. G., Dixon, J. C., and Schlyter, P.: The chemical weathering regime of Karkevagge, arctic-alpine Sweden, Geomorphology, 41, 37-52, 2001.

Ulrich, M., Hauber, E., Herzschuh, U., Härtel, S., and Schirrmeister, L.: Polygon pattern geomorphometry on Svalbard (Norway) and western Utopia Planitia (Mars) using high-resolution stereo remote-sensing data, Geomorphology, 134, 197-216, 2011.

Újvári, G., Varga, A., and Balogh-Brunstad, Z.: Origin, weathering, and geochemical 20 composition of loess in southwestern Hungary, Quaternary Res., 69, 421-437, 2008.
Vandenberghe, J.: Grain size of fine-grained windblow sediment: a powerfull proxy for process indentification, Earth. Sci. Rev, 121, 18-30, 2013.

Varga, A., Ujvari, G., and Raucsik, B.: Tectonic vs. climatic control on the evolution of a loess-paleosol sequence at Bermend, Hungary: an integrated approach based on paleoecological, clay mineralogical, and geochemical data, Quatern. Int., 240, 71-86, 2011.

Velle, J. H.: Holocene sedimentary environments in Smeerenburgfjorden, Spitsbergen, M.S. thesis, University of Troms $\varnothing$, Norway, 128 pp., 2012.

Vinther, B. M., Clausen, H. B., Johnsen, S. J., Rasmussen, S. O., Andersen, K. K., Buchardt, S. L., Dahl Jensen, D., Seierstad, I. K., Siggaard-Andersen, M. L., Steffensen, J. P., Svensson, A., Olsen, J., and Heinemeier, J.: A synchronized dating of three Greenland ice cores throughout the Holocene, J. Geophys. Res., 111, D13102, doi:10.1029/2005JD006921, 2006.

Wanner, H., Beer, J., Butikofer, J., Crowley, T.J., Cubasch, U., Fluckiger, J., Goosse, H., Grosjean, M., Joos, F., Kaplan, J. O., Kuttel, M., Muller, S. A., Prentice, I. C., Solomina, O., Stocker, T. F., Tarasov, P., Wagner, M., and Widmann, M.: Mid-to Late Holocene climate change: an overview, Quaternary Sci. Rev., 27, 1791-1828, 2008.

Watanabe, T., Matsuoka, N., and Christiansen, H. H.: Mudboil and ice-wedge dynamics investigated by electrical resistivity tomography, ground temperatures and surface movements in Svalbard, Geogr. Ann. A., 94, 445-457, 2012a.

Watanabe, T., Matsuoka, N., and Christiansen, H. H.: Controls on patterned ground variability at a continuous permafrost site, central Spitsbergen, Proceedings of the Tenth International Conference on Permafrost, 1, 433-438, 2012b.

Watanabe, T., Matsuoka, N., and Christiansen, H. H.: Ice- and soilwedge dynamics in the Kapp Linné Area, Svalbard, investigated by two- and three-dimensional GPR and ground thermal and acceleration regimes, Permafrost Periglac., 24, 39-55, 2013.

Zech, M., Zech, R., Zech, W., Glaser, B., Brodowski, S., and Amelung, W.: Characterisation and paleoclimate of a loess-like permafrost paleosol sequence in NE Siberia, Geoderma, 143, 281-295, 2008. 